WORLD VIEW

\title{
Distribution and shifting trends of bacterial keratitis in north China (1989-98)
}

\author{
X Sun, S Deng, R Li, Z Wang, S Luo, X Jin, W Zhang
}

See end of article for

Br J Ophthalmol 2004;88:165-166. doi: 10.1136/bjo.2003.011205

authors' affiliations

Correspondence to: Professor S Xuguang, Eye Microbiology Department, Beiiing Institute of Ophthalmology, Beijing 100005. China; sunxuguang@yahoo.com

Accepted for publication 13 June 2003

\begin{abstract}
Aims: To study the distribution and shifting trends of bacterial keratitis.
Methods: The data of 2220 corneal isolates from 1 January 1989 to 31 December 1998 were reviewed retrospectively.

Results: Positive culture was recovered in 490 isolates. Gram positive cocci and Gram negative bacilli represented $51 \%$ and $39.4 \%$, respectively. Pseudomonas aeruginosa was the most common pathogen (32.2\%). A gradual increase in the percentage of Gram positive cocci coupled with a decrease of Gram negative bacilli.

Conclusion: Pseudomonas aeruginosa and coaculase negative Staphylococcus were the most common pathogens in bacterial keratitis in north China.
\end{abstract}

K eratitis caused by bacteria usually results in various corneal lesions, and even severe visual loss. In developing countries, bacterial keratitis has become the most common cause of corneal blindness. ${ }^{1}$ Based on data over 10 years (1989-1998), we carried out a detailed aetiologic analysis.

\section{MATERIAL AND METHODS}

From 1 January 1989 to 31 December 1998, bacterial cultures were carried out on 2220 cases. Culture media: blood agar plate, routine culture media, and identified culture media. Specimens were inoculated on culture media in $35^{\circ} \mathrm{C}$ for $24-$ 48 hours.

\section{RESULTS}

Of the 2220 corneal isolates, mono-bacterial positive culture was recovered in 490 isolates (table 1). Gram positive cocci were found in 250 isolates $(51.0 \%)$; most of these were coagulase negative Staphylococcus. Gram positive bacilli isolates accounted for $45(9.2 \%)$. Gram negative bacilli isolates were found in 193 (39.4\%), mainly Pseudomonas spp (see table 2).

The gradual increase in the percentage of Gram positive cocci $(25 \%$ in $1991 v 70.8 \%$ in $1997, \mathrm{p}<0.01)$, and decreasing trend in Gram negative bacilli (69\% in 1990 v 23.4\% in 1997, $\mathrm{p}<0.01$ ), are shown in figure 1 .

The percentage of Pseudomonas spp followed a trend of decrease $(58.6 \%$ in $1990 \vee 24 \%$ in $1998, \mathrm{p}<0.01)$, as shown in figure 2 .

\section{DISCUSSION}

According to our study, Gram positive cocci is still the leading causative organism of bacteria keratitis, and the percentage
Table 2 Distribution of organisms in positive bacterial cultures (1989-98)

\begin{tabular}{|c|c|c|}
\hline & $\begin{array}{l}\text { No of bacterial } \\
\text { isolates }\end{array}$ & $\begin{array}{l}\% \text { of total } \\
\text { bacterial isolates }\end{array}$ \\
\hline Gram positive cocci & 250 & $51 \%$ \\
\hline $\begin{array}{l}\text { Staphylococcus } \\
\text { epidermidis }\end{array}$ & 91 & $18.6 \%$ \\
\hline Micrococcus spp & 54 & $11 \%$ \\
\hline Staphylococcus aureus & 27 & $5.5 \%$ \\
\hline $\begin{array}{l}\text { Streptococcus } \\
\text { pneumococcus }\end{array}$ & 59 & $12 \%$ \\
\hline Streptococcus viridans & 17 & $3.5 \%$ \\
\hline Others* & 2 & $0.4 \%$ \\
\hline Gram positive bacilli & 45 & $9.2 \%$ \\
\hline $\begin{array}{l}\text { Corynebacterium } \\
\text { commune }\end{array}$ & 36 & $7.4 \%$ \\
\hline Bacillus spp & 1 & $0.2 \%$ \\
\hline Nocardia actinomycete & 1 & $0.2 \%$ \\
\hline Others* & 7 & $1.4 \%$ \\
\hline Gram negative cocci & 2 & $0.4 \%$ \\
\hline Branhamella catarrhalis & 2 & $0.4 \%$ \\
\hline Gram negative bacilli & 193 & $39.4 \%$ \\
\hline Pseudomonas spp & 158 & $32.2 \%$ \\
\hline Acinetobacter spp & 7 & $1.4 \%$ \\
\hline Moraxella spp & 1 & $0.2 \%$ \\
\hline Enterobacteriaceae & 21 & $4.3 \%$ \\
\hline Flavobacterium spp & 2 & $0.4 \%$ \\
\hline Others* & 4 & $0.8 \%$ \\
\hline Total bacterial isolates & 490 & \\
\hline
\end{tabular}

*Bacteria specimens not identified under the conditions of our laboratory

of Gram positive cocci showed an increased trend. Pseudomonas spp accounted for $32.2 \%$ of the total corneal positive cultures, but it decreased year by year. The data from

Table 1 Number and ratio of bacterial cultures by year

\begin{tabular}{lccccccccccc}
\hline & 1989 & 1990 & 1991 & 1992 & 1993 & 1994 & 1995 & 1996 & 1997 & 1998 & Total \\
\hline Corneal cultures & 119 & 156 & 210 & 250 & 246 & 249 & 214 & 231 & 277 & 268 & 2220 \\
Positive cultures & 27 & 29 & 36 & 73 & 41 & 57 & 41 & 42 & 64 & 80 & 490 \\
(\% of corneal cultures) & 22.7 & 18.6 & 17.1 & 29.2 & 16.7 & 22.9 & 19.2 & 18.2 & 23.1 & 29.9 & 22.1 \\
\hline
\end{tabular}




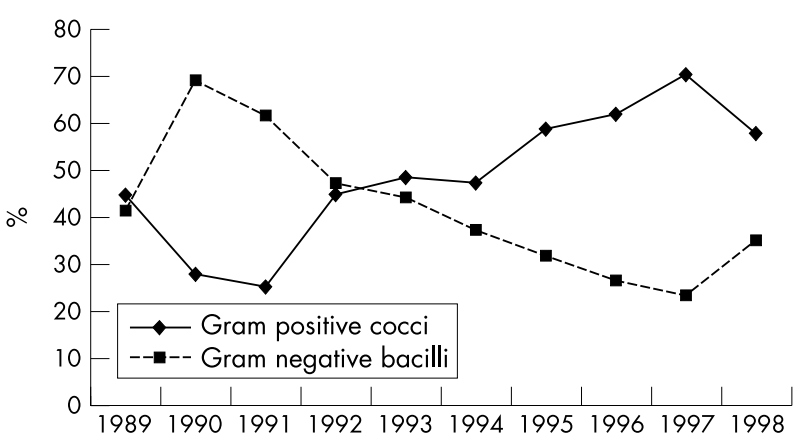

Figure 1 Shifting trends of different organisms by year.

America showed that $P$ aeruginosa accounted for $25.7 \%$ of total positive bacterial isolates. ${ }^{2}$

A study in India showed that Gram positive organisms accounted for $82.4 \%$, while Gram negative organisms $16.1 \%^{3}$. Compared with that study, our data from north China have shown a lower percentage of Gram positive bacteria and a relatively higher percentage of Gram negative for ketatitis.

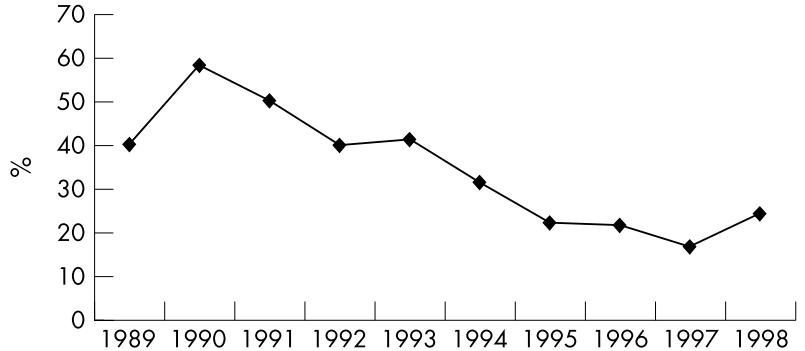

Figure 2 Shifting trend of Pseudomonas spp isolates by year.

\section{Authors' affiliations}

X Sun, S Deng, R Li, Z Wang, S Luo, X Jin, W Zhang, Eye Microbiology

Department, Beijing Institute of Ophthalmology, Beijing, China

\section{REFERENCES}

Wilhelmus KR. Bacterial keratitis. In: Pepose JS, Holland GN, Wilhelmus KR, eds. Ocular Infection \& Immunity. USA: Patterson AS, 1996:973.

2 Alexandrakis G, Alfonso EC, Miller D, et al. Shifting trends in bacterial keratitis in south Florida and emerging resistance to Fluoroquinolones. Ophthalmology 2000;107:1497-1502.

3 Garg P, Rao GN. Corneal ulcer: Diagnosis and management. Community eye Health 2000;12:21-4.

\section{$\mathrm{ECHO}$}

\section{New mutations in the PAX6 gene in patients with aniridia}

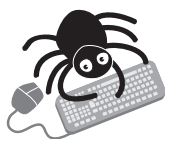

Please visit the British Journal of Ophthalmology website [www. bjophthalmol. com] for a link to the full text of this article. hree novel mutations in the PAX6 gene have been found in patients with aniridia, adding to the data base of more than 200 different mutations in this gene.

Overall, aniridia has an incidence of about $1 / 80$ 000, and mutations in the PAX6 gene on chromosome $11 \mathrm{pl} 3$ are responsible for about $80 \%$ of cases, both sporadic and familial. Normal eye development is highly susceptible to the degree of PAX6 expression. Haploinsufficiency causes aniridia and overexpresssion leads to microphthalmia.

The three new recently reported mutations were found in patients who were all heterozygous for their mutation. In one instance the mutation was found in three members of the same family-brother, sister and mother.

The PAX6 gene encodes a transcriptional regulator and produces two alternative splice isoforms that have distinct DNA binding specificities. Mutations are found throughout the gene so that extensive investigation is required in each case. The new mutations reported are all from unrelated families, and all probably lead to a truncated PAX6 protein. The first family carried a nonsense mutation in exon 8, another patient had a mutation in exon 10 and the third patient had a mutation which lead to aberrant mRNA splicing.

These findings indicate further the need for comprehensive genetic counselling in patients with aniridia in whom PAX6 mutations are detected.

A Journal of Clinical Pathology: Molecular Pathology 2003;56:180-183. 